\title{
STRUGGLES IN SUZANNE COLLINS' NOVEL THE HUNGER GAMES
}

\author{
Intan Novia Sari and Purwarno \\ Faculty of Literature, Universitas Islam Sumatera Utara, Medan, Indonesia \\ e-mail: intantanov@gmail.com
}

Received: 31 January 2019

Accepted: 20 July 2019

\begin{abstract}
This research is the result of qualitative research on the protagonist's struggles named Katniss Everdeen depicted in Suzanne Collins' novel The Hunger Games. Burleson (1964) says that struggle is one of ways to reach the better life in the future and also to increase the prestige. It means that any hope will be achieved through struggling. Katniss Everdeen is a strong as well as a resourceful sixteen-year-old girl who is far more mature than her age would suggest. Katniss is the main provider in her family, which consists of Katniss, her mother, and her younger sister, Prim Everdeen. She must struggle hard to make herself and her family stay life. Therefore she always keeps on struggling in her life. The finding of this research shows that the protagonist is succesful in her struggles to fulfill her family needs, to protect her sister and to win in the Hunger Games.
\end{abstract}

Keywords: struggle, prestige, protection, hunger games

\section{Introduction}

The Hunger Games, published in 2008, is a science novel by Suzanne Collins, an outstanding American writer. It is written in the voice of 16-year-old, Katniss Everdeen, who lives in Dystopian, post-apocalyptic nation of Panem in North America. The Capitol, a highly advanced metropolis, exercises political control over the rest of the nation. The Hunger Games is an annual event in which one boy and one girl aged 12-18 from each of the twelve districts surrounding the Capitol are selected by lottery to compete in a televised battle to the death.

The novel received mostly positive feedback from major reviewers and authors. It is praised for its storyline and character development, though some reviewers have noted similarities between Collins' The Hunger Games and Koushun Takami's Battle Royale (1999). In writing The Hunger Games, Collins drew upon Greek mythology, Roman gladiatorial games, and contemporary reality television for thematic content. The Hunger Games won many awards, including "The California Young Reader Medal", and was named one of the Publishers Weekly's "Best Books of the Year" in 2008.

The Hunger Games was published in September 2008 and quickly found critical success by reviewers and authors. Among the features that received the most attention were the plotting and pace. Collins has attributed her skill in these areas to her background as a playwright and her time spent working in television, where there is little downtime allowed and character development has to occur simultaneously with the storyline constantly moving forward. The book also rose to the top of the New York Times bestseller 
list and subsequently spent more than three consecutive years on the list. The other books in the trilogy, published over the next two years, followed the same pattern, all becoming huge commercial successes. Then, in March 2012, The Hunger Games movie was released. It had the third-highest opening weekend in history, and the highest opening weekend ever for a movie that was not a sequel. There are now more than 18 million copies of The Hunger Games in print, and with the trilogy now available in fifty languages, the books have genuinely become a worldwide phenomenon. http://www.sparknotes.com/lit/the-hunger-games/context.html). The novel is the first in The Hunger Games trilogy, followed by Catching Fire (2009) and Mockingjay (2010). The Hunger Games is one of Suzanne Collins' masterpieces, and constitutes one of the best novels in 2008. This novel portrays the differences of life between the situation of the districts and the modern life. The novel is concerned with struggles, suffering, threats of war, authoritarian goverments, obsession with fashion trends, etc.

\section{Literature Review}

This research analyzes the struggles of the protagonist named Katniss Everdeen depicted in Suzanne Collins's novel, The Hunger Games. According to Paulo (2011: 3), the term struggle is defined as "to try extremely hard to achieve something, even though it is very difficult and impossible." While, Collins (1987: 1658) defines struggle as "to try hard to do something". Based on the definitions of the struggle quoted above, it can be inferred that struggle is to try very hard to do or to achive something no matter how difficult it is. Struggle usually brings positive effects for people because without it, people cannot run a good life, and will not be able to find the ways to reach whatever they dream of.

The word "protagonist" comes from the Greek word "protagonistes", meaning "first combatant" and refers to the leading character, aided by the chorus, in classical Greek tragedy. It means that the protagonist is the leading character in a work, often playing the rule of the hero or heroine.

Abrams (1981: 212) defines that "protagonist is the chief character in a plot, on whom our interest centers (or alternatively, the hero or heroine)." Originally, in ancient Greek theatre, the protagonist was the principal actor in drama. Wiley (2010:33) defines that "protagonist is a person who plays a leading or active part." Hull (2013:5) says that "protagonist is who the story is about." He also states that "protagonist pursues the goal of the story who, sometimes, is played by the main character. The protagonist represents the audience's eyes into the story because he or she will effect the audience emotionally."

It is in line with what is said by Fowler (1987: 32), who claims that "the protagonist is the main character in a story, novel, drama, or other literary work, the character that the reader or audience empathizes with." According to Beckson and Ganz (1990: 217), in Greek drama, a protagonist is the first actor, who played the leading part and doubled in some minor roles. Basically, a protagonist refers to the most important character, usually a hero or heroine in a story. A protagonist is the central character or leading figure in poetry, narrative, novel or any other story. A protagonist is sometimes called a "hero" by the audience or readers. (http://literarydevices.net/protagonist).

Based on some definitions of protagonist above, a protagonist can be defined as the first charactor in a literary work, who is always prioritized by audience or the reader of literary work that can cause sympathy for the audience or the reader. A protagonist is a very important tool used in developing a story. There are different terms used for a protagonist such as a hero, focal character, central character, the first character, etc. 
Regardless of what title you give a protagonist, she or he remains the key ingredient in the development of the story, which is why the story revolves around him or her.

In this world, people of every race, color, and culture all share something in common even without knowing it; that is they all have struggles in the way they live their lives. No one can deny the fact that life in the world is one continual struggle. The one who does not know the struggle of life is either an immature soul, or a soul who has risen above the life of this world. The object of a human being in this world is to attain to the perfection of humanity, and therefore it is necessary that man should go through what we call the struggle of life. Frederick Douglass says that "if there is no struggle, there is no progress." Further, Junethea Crystal Centeno states that:

"Sometimes, struggle are exactly what we need in our life. If we were to go through our life without any obstacles, we would be crippled. We would not be as strong as what we could have been. Give every opportunity a chance, leave no room for regrets." (http://thinkexist.com/quotations/struggle).

Burleson (1964: 30) says that "struggle is one of ways to reach the better life in the future and also to increase the prestige. It means that any hope will be achieved through struggling." To support Burleson, Collins (1978: 1451) defines that "struggle is not easy, sometimes it also needs sacrifice in order to get purpose. Although, happy ending will not always come as the result of the struggle."

Sri Swami Krishnananda (1989: 5) says that struggle might be fulfilled by various ways. It is due to different barriers and limitations faced by everyone in his or her life. In addition, someone who has different dream may have different struggle. However, one who really wants to achieve his or her goal in life, he or she will struggle hard to face any obstacles coming to him or her.

Human life may be regarded as a process of successive achievements, and every movement in this process is a step taken towards the actualization of the ideal which beckons one to itself. All beings, whatever be in the cosmos, are comprehended by this single law, the law of a striving for higher achievements. In this struggle to achieve the higher, one realizes pleasure. It is well said that man never is; he is always to be. We do not entirely live in the present. There is an element of the future in what we do, and we never confine ourselves to the present merely. This means to say that we identify ourselves, though in a covert manner, with an ideal to be achieved in the future, which, we hope, will bring us a larger satisfaction. If the future is not ingrained in the present, how could there be such a thing as hope? That we cannot keep quiet, that we always feel a duty before us, is enough indication that we are wound up with a future. It is also not true that we wholly live in the future, because the future cannot be contained in the consciousness of the present. Time cannot take a jump beyond the present, which is its core. We might hope for the future, but we cannot live in the future. Life is always a present.

If, then, it is impossible to have a real satisfaction in the future, and we cannot also live without a future, there will appear to be a tension, or contradiction, in our life. Life is a battle between the present and the future, between our affairs of today and our future hopes. The present and future cannot join in time, and yet there seems to be a superhuman element, transcending human understanding which somehow connects the two together. With all this, still, we know that the present and the future never come together. All this may look like a logical untenability, but logic is not all, and science is not everything. What, to us, seems a possibility, need not exhaust all wisdom. We cannot understand how 
it is possible to reconcile our present difficulty with our longings of the future. We seem to be wanting something which is not within our present perception, and feel happy about what we know not. We seem to be fighting with time itself, which bifurcates the present from the future. And what we want is not bifurcation but union of the present and future.

Struggle is to progress with difficulty, to make a strenuous effort or to be strenuously engaged with a problem, task, or undertaking (http://www.thefreedictionary.com/struggle). Effort and struggle are directed towards the achieving of an end which is realized as one's ideal and which mostly remains as a future to the reality of the present state of affairs.

Life's struggle has been, at least at its lowest level, for the overcoming of difficulties in the form of hunger and thirst, heat and cold and the fear of death, all whichever remain as the invariable concomitants of life in general. (Krishnananda, 1989: 1)

Struggle is done for overcoming our own and other's difficulties. First, we struggle with other people. That means that every relationship is broken by sin, and because nothing works perfectly because we have competition, we have conflict, and we have misunderstandings. You get disappointed by other people and other people are disappointed in you. Secondly, we struggle with ourselves. Your biggest battle in life really is not with other people. Our biggest battle is inside us. We struggle with our fears, struggle with our flaws, struggle with our temptations, struggle with our insecurities, struggle with guilt, struggle with re gret and struggle with resentment, compulsions, weaknesses, sins, addictions and struggle to make sense life.

Roehm (2011: 11) describes that life is a struggle and the rewards you get are from meeting your difficulties head on, face to face, overcoming them and moving onto your next struggle along your stepping stone to success. The details of struggles of human in their life are of some kinds. The first struggle is human works in effort for man to obtain or work for salvation of the human soul. Human works defy God's grace. Human works oppose the Grace of God. In the eyes of God it is impossible for man to find salvation of the soul by human works. The second struggle is the "inner struggle" that some people encounter after they are saved. This is a struggle that forms from a conflicting carnal nature those wars with the Divine nature received in the new birth. The struggle caused from the carnal nature feeds on man's interests, strange doctrines, traditions, imaginations, and religions that teach that man cannot get rid of such nature. The third struggle is the "outer struggle" that men encounter in life. This struggle can stem from economic problems, domestic problems, doctrinal problems, or any other outer conditions that men are subjected to in life.

Life struggles come in many kinds. Some struggles may be regarding money, love, careers or about things we cannot fathom, at cetera. Our life struggles know no age, race, and religion or where you are located in this vast world.

Struggle means any personal goal achievement accompanied by discomfort and resistance. This leaves out struggles of an interpersonal kind. There are many forms of struggle, but for simplicity's sake, Maizler (2012: 67) divides struggle into four kinds. They are negative, positive, inevitable, and chosen struggles.

(a) Negative struggle is goal achievement to eliminate a deficit state. This occurs when you are attempting to get back to the norm, such as mastering a life limiting phobia.

(b) Positive struggle is goal achievement that involves transformation from your steady state into a more evolved, grown, or developed state of being. Positive struggle, in contrast to negative struggle does not involve overcoming pathology. Examples of 
positive struggle are going to graduate school or writing a book. Positive struggle may still certainly involve overcoming resistance and discomfort.

(c) Inevitable struggle deals with the necessary losses and attendant discomfort that are conditions of your life in this world. As your mother struggled to birth you, you struggled to adjust to a new and less comforting world. During your life, you will struggle with sadness and loss when your friends, parents, or partners die or go elsewhere. These struggles are an automatic condition of your life.

(d) Chosen struggles are the product of personal choice and are not automatic conditions of life. Simple examples of chosen struggles are climbing a mountain, going to graduate school, or becoming a body builder.

\section{Research Method}

The researchers are interested in this topic because in The Hunger Games, Suzanne Collins describes the struggles of a very young woman who is only a lay girl from the lower society. Besides, this subject matter is also pregnant with moral lessons. It can inspire girls in general that girls can do things appropriately done by man, and even can perform responsibilities better than man can. It also inspires us to be brave to encounter any obstacles in this life, and to have undefeated wills to struggle for everything in order to materialize the dreams as well as objectives in this life.

Furthermore, this research is aimed at revealing the struggles carried out by the protagonist and how the protagonist carries out her struggles. Therefore, the scope of the research focuses on the protagonist's struggles. The strugles of the protagonist analyzed in this research covering the protagonist's struggle to fulfill her family needs, to win in the Hunger Games, and to protect her sister.

In finishing the analysis in this research, the researchers adopt qualitative research method. Qualitative research method is conducted by studying the organized material in order to discover inherent facts. The content analysis, inductive analysis, and logical analysis are mostly used in the analysis of qualitative material (Koul, 1984: 1990).

\section{Discussion}

One of the common cases that can be seen often in life, history and even literature is those of struggle. People struggle against things on both a superficial level and an actual level. For example, one could be constantly struggling against the opinion of others, or the pressures of society, or maybe even time. On the other hand, one can experience physical struggle with a person, a group, an illness, etc. Actual struggles often are with things that cannot be stopped or experienced with the senses. These kinds of struggles are the most common in literature. In Suzanne Collins's Novel The Hunger Games, the protagonist of the novel must struggle to fulfill the family needs, to win in the Hunger Games, and to protect her sister from the risks that may cause death to her sister.

\subsection{To Fulfill the Family Needs}

The protagonist of the novel named Katniss Everdeen lives in a life filled with anxiety, fear and tears, such as the reaping, the food shortages and the hunger games. In Panem, all districts are ruled by the Capitol. When Katniss was eleven years old, her father was blown to bits in a mine explosion that there was nothing even to bury. Since the death of her father, her mother is falling into a deep depression so Katniss must struggle to fulfill her family needs. Katniss must perform the function of a father because 
her mother has failed to do so. As the oldest child in her family, Katniss feels that it is her responsibility to fulfill the needs of her family.

Actually, Katniss feels irritated as well as dissapointed with her mother because her mother continuously dissolves in grief. However, Katniss must pretend to be steadfast as well as unwavering in order to keep his family live especially her sister, Prim. Katniss' dissapointment is seen in the following quotation:

I try to remember that when all I can see is the woman who sat by, blank and unreachable, while her children turned to skin and bones. I try to forgive her for my father's sake. But to be honest, I'm not theforgiving type. (Collins, 2009: 8)

The above quotation shows Katniss' disappointment to her mother because her mother constantly melts into sorrow due to the death of her husband. Since the death of Katniss' father, her mother does nothing for the family needs. She is unable to think normally that she does not care of the condition of her children that her children turn to skin and bones.

The condition of her mother makes their lives worse that Katniss must struggle herself to fulfill her family needs. She fulfills her family need by hunting, doing barter and doing exchange for tesserae. In order to get food for her family, Katniss must go hunting to the wild wood which is inhabitted by wild dogs, lonecougars and bears.

I swing my legs off the bed and slide into my hunting boots. Supple leather that has molded to my feet. I pull on trousers, a shirt, tuck my long dark braid up into a cap, and grab my forage bag. ...

Our house is almost at the edge of the Seam. I only have to pass a few gates to reach the scruffy field called the Meadow. Separating the Meadow from the wood, in fact enclosing all of District 12, is a high chain-link fence topped with barbed-wire loops. In theory, it's supposed to be electrified twenty-four hours a day as a deterrent to the predators that live in the wood-packs of wild dogs, lonecougars, bears-that used to threaten our streets. (Collins, 2009: 4)

The above quotation tells us that Katniss' struggle to fulfill her family needs is not easy and full of risks. She must encounter many obstacles in the wood. Katniss must have sorts of ways to get some hunted animals in the wood. Before she could reach a meadow in which she can hunt the expected animals, she must pass a high chain-link and electrified fence topped with barbed-wire loops. She must be able to take a good moment and listen carefully for the hum showing that the fence is equipped with electricity. At the time when the hum stops, she must jump the fence. Katniss has to fulfill her family needs by hunting illegally beyond the boundaries of District 12 .

Although hunting is illegal in Panem, Katniss has no choice but to do that for the shake of the family needs. Through her skill with a bow and her ability to track and snare rabbits and squirrels, her family has been able to survive.

Inside the woods they roam freely, and there are added concerns like venomous snakes, rabid animals, and no real paths to follow....

Even though trespassing in the woods is illegal and poaching carries the severest of penalties, more people would risk it if they had weapon. But most are not bold enough to venture out with just a knife. My bow is a rarity, crafted by my father along with a few others that I keep well hidden in the woods, carefully wrapped in waterproof covers. My father could have made good money selling them, but if the officials found 
out he would have been publicy executed for inciting a rebellion.

(Collins, 2009: 5)

The above quotation tells that Katniss has his ways to get food by hunting in the wood. Althugh it is illegal and the severest penalties are awaited for those who are captured, she takes the risks. She is lucky as before her father passed away, her father had taught her some techniques to hunt. Her father is a skillful man in crafting a bow that Katniss now has an extraordinary one.

Katniss has a best friend who becomes his hunting partner, named Gale Hawthorne. He is also from District 12 and his father was killed in the same mining accident as Katniss's. They always hunt and gather some fresh fruits and vegetables together and then they exchange or barter some of them with other people.

On the way home, we swing by the Hob, the black market that operates in an abandoned warehouse that once held coal. ...

We easily trade six of the fish for good bread, the order two for salt. Greasy Sae, the bony old woman who sells bowls of hot soup from a large kettle, takes half the greens off our hands in exchange for a couple of chunks of paraffin.

When we finish our business at the market, we go to the back door of the mayor's house to sell half of the strawberry. (Collins, 2009: 11)

The above quotation shows what Katniss and Gale do when they have finished their hunting. On their way home, Katniss and Gale call at a black market and the mayor's house to trade and exchange a portion of their hunting results and the fruits and vegetables they have gathered in the wood with other things that they need, such as bread, salt, paraffin etc, because in the district 12 they are more in need of useful things compared with money.

Katniss also signs up for the tesserae to fulfill her family needs, a ration of grain that is given in exchange for placing your name in the lottery for the reaping, the ceremony that determines who will be the district's representative in the Games. It is seen in the following quotation:

Say you are poor and starving as we were. You can opt to add your name more times in exchange for tesserae. Each tesserae is worth a meager year's supply of grain and oil for one person. You may do this for each members as well. So, at the age of twelve, I had my name entered four times. Once, because I had to, and three times for tesserae for grain and oil for myself, Prim, and my mother. In fact, every year I have needed to do this. And the entries are cumulative. So now, at the age of sixteen, my name will be in the reaping twenty times. (Collins, 2009: 13)

The quotation above shows the other way of Katniss's struggles to fulfill her family needs. She should exchange her name for the tesserae since each tesserae is worth a meager year's supply of grain and oil for one person. As the result, the possibelities of being the one whose name is called increase. Katniss does it to fulfill her family needs so that they can get some food and other needs, but she will get more chances for the reaping in the hunger games.

In district 12, all forms of stealing are strickly prohibitted. Anyone who breaks the rules will be sentenced to death. The punishment is so scared that Katniss is scared to do 
it. She should not steal but she also does not want to see her mother and sister die of starvation. She really feels uneasy but she should find food for her family.

All forms of stealing are forbidden in District 12. Punishable by death.

But it crossed my mind that there might be something in the trash bin, and those were fair game. Perhaps a bone at the bucher's or rotted vegetables at the grocer's, something no one but my family was desperate enough to eat. Unfortunately, the bins had just been emptied. (Collins, 2009: 29)

The quotation above tells how Katniss who feels distressed to return home because she does not get any food to take home. She cannot bear to see the faces of her mother and sister who have been waiting her at home. She knows well that her family is desperate enough to eat now, but it is impossible for her to steal because all forms of stealing are forbidden in District 12 and the punishment is death. She seeks something in trash bin but it has just been emptied.

\subsection{To Protect Her Sister}

Katniss has a sister, named Prim Everdeen whom she loves above all others. Katniss knows that Prim will not be able to survive the reaping so that she does everything to protect her sister. Katniss exchanges her name for tesserae, and does not allow her sister to exchange her name for tesserae.

I hug her, because I know these next few hours will be terrible for her. Her first reaping. She's about as safe as you can get, since she's only entered once. I wouldn't let her take any tesserae. But she's worried about me. That the unthinkable might happen.

I protect Prim in every way I can, but I'm powerless against the reaping. The anguish I always feel when she's in pain wells up in my chest and threatens to register on my face. (Collins, 2009: 15)

The quoation above tells that Katniss and Prim love each other. In Prim's first reaping, Katniss does not feel so worried because Prim's chance to be elected in the reaping is so remote since her name is only entered once. Katniss has promised to himself to protect her sister in every way she can.

But at the reaping for the 74th annual hunger games, when Effie Trinket reads out the name in the slip of paper in a clear voice, Katniss is shocked and disappointed. The name of her sister, Primrose Everdeen is in fact elected to the hunger games among the thousand slips of paper. It is really beyond her expectation that the name of her sister is chosen to the hunger games.

There must some mistake. This can't be happening. Prim was one slip of paper in thousands! Her chances of being chosen so remote that I'd not even bothered to worry about her. Hadn't I done everything? Taken the tesserae, refused to let her do the same? One slip. One slip in thousands. The odds had been entirely in her favor. But it hadn't mattered. (Collins, 2009: 21)

The quotation above tells how Katniss feels shocked when Prim's name is pulled by District 12 chaperone, Effie Trinket. The hunger games is the same with the death, and Katniss will not let her sister die. Whereas Prims never exchanges her name for tesserea and she still tweleve years old so that her name is only one slip of paper in the drawing. Katniss really cannot believe what has happened. 
When Katniss hears that Prim becomes one of tribute in the hunger games, she feels so sad and weak. However, she regains her spirit soon and plans to protect her sister. It is seen in the following quotation:

"Prim!" the strangled cry comes out of my throat, and my muscles begin to move again. "Prim!"

"I volunteer!" I gasp. "I volunteer as tribute!” (Collins, 2009: 22)

The quotation above tells that Prim is walking with stiff and small steps up toward the stage, but Katniss immediately walks to the stage too. Katniss pushes Prim behind her and states that she volunteers to take her sister's place as a tribute from District 12 to the hunger games. Katniss thinks that it is a right decision to protect her sister from the hunger games, because Katniss does not want to let her beloved sister be a tribute in the hunger games. Katniss knows that her sister will die if she becomes a tribute in the hunger games, and she does not want to lose her sister. She does not care of her own safety in order to protect her sister.

\subsection{To Win in the Hunger Games}

Hunger Games is a compulsory annual death match which is a kind of punishment for the uprising all of Panem's 12 districts. The twelve districts in Panem must provide one girl and one boy, called tributes, to paticipate for over a period of several weeks in the hunger games. The competitors must fight to the death, and the last tribute standing is declared as the winner who will be showered with prize. The hunger games will be watched on the television by all of the twelve districts, and this is the capitol's way of reminding the districts how totally they are at the Capitol's mercy.

Katniss must use many tricks in his struggling to be a winner in the hunger games. She and Peeta, Katniss' fellow tribute from District 12, are to be mentored by Haymitch Abernathy, the only alive tribute of the District 12, who has ever become a winner in the hunger games. Katniss must hear all of her mentor says. It is seen in the following quotation:

"One thing at a time. In a few minutes, we'll be pulling into the station.

You'll be put in the hands of your stylists. You' re not going to like what

they do to you. But no matter what it is, don't resist." Says Haymitch.

(Collins, 2009: 58)

The quotation above shows how Haymitch explains and informs any things dealing the hunger games to Katniss and Peeta. Haymitch reminds Katniss to follow all done by her stylists, Cinna. During the presentation of the tributes, Cinna includes live flames in Katniss' costume with a little synthetic fire. It is spesifically designed by Cinna because in the opening ceremonies, the tributes supposed to wear something that suggests their district's principal industry, and in District 12 the principal industry is coal. The sythetic fire custom worn by Katniss makes the audiences easy to recognise her when she is in the arena. Katniss will be recognised as a girl with fire custom. Furthermore, Katniss will get some sponsors that give her a little extra help, some food, the right weapon in the Cornucopia or battlefield of the hunger games.

Katnis makes some special tricks to get some sponsors in the hunger games. She does her utmost to get eleven points in the training centre with excellent shooting from her bow, and makes the dramatic love with Peeta so that they are remembered by the audience as "the star crossed lovers from District 12". It is seen in the following quotation: 
Back in the center of the gymnasium, I take my initial position and skewer the dummy right through the heart. Then I sever the rope that holds the sandbag for boxing, and the bag splits open as it slams to the ground. Without pausing, I shoulder-roll foward, come up on one knee, and send an arrow into one of the hanging lights high above the gymnasium floor. A shower of sparks bursts from the fixture. ...

Suddenly I am furious, that with my life on the line, they don't even have the decency to pay attention me ..

Without thinking, I pull an arrow from quiver and send it straight at the gamemakers' table. I hear shouts of alarm as people stumble back. The arrow skewers the apple in the pig's mouth and pins it to the wall behind it. (Collins, 2009: 101-102)

I dig my fingernails into my palms as my face come up, expecting the worst. Then they're flashing the number eleven on the screen. (Collins, 2009: 108)

Now they all do. You're all they're talking about. The star-crossed lovers from District Twelve!" says Haymitch. (Collins, 2009: 135)

The quotation above tells that Katniss searches some ways to get many sponsors to help her in the battlefield. There is a private session with the Gamemakers in the training centre and all tributes must get a good score because the score can give the audience a starting place for the betting that will continue throughout the games, and the number of scores will influence the sponsors to support the tributes. The number, which is between one and twelve, one being irredeemably bad and twelve being unattainably high, signifies the promise of the tributes. In her efforts, Katniss succeeds to make a excellent shooting but the Gamemakers ignore her. It drives her angry so that she shoots her arrow at the Gamemaker's table. Actually it is one of the dangerous actions which would threaten her life but finally she is lucky, Katniss succeeds to get eleven for her score and she gets the top training score. On the day of the tribute interviews, Peeta, a boy from District 12 reveals that he has had a crush on Katniss ever since he can remember, and Haymitch, a mentor of District 12 has a plan to make a dramatic love so that all people know them as "The star-crossed lovers from District 12."

The seventy-fourth hunger games begin in Cornucopia, in the mouth of a giant golden, spilling over with the things that will give the tributes life in the arena. Katniss moves out immediately, puts as much distance as she can between herself and the others, and finds a source of water. Katniss wants a silver sheath of arrows and a bow but she only gets a bright orange backpack. She must struggle to get them from other tributes.

There, resting on a mound of blanket rolls, is a silver sheath of arrows and a bow, already strung, just waiting to be engaged. That's mine, I think. It's meant for me. (Collins, 2009: 149)

And I've missed it! I've missed my chance! ...

I sprint in twenty yards to retrieve a bright orange backpack that could hold anything because I can't stand leaving with virtually nothing. A boy, I think from District 9, reaches the pack at the same time I do and for a brief time we grapple for it and he coughs, splattering my face with blood...

Already other tributes have reached the Cornucopia and are spreading out to attack. (Collins, 2009: 150) 
From the quotation above, it is seen that Katniss must struggle hard to stay alive in the games. She must be faster than other tributes to win. Although she only gets a bright orange backpack, but there are a few things in the backpack that she can use to help and defend herself in the arena.

In the hunger games, Katniss makes an ally with Rue, a girl tribute from District 11 that reminds her with Prim. Rue has helped Katniss when she is nearly killed by the Careers. Katniss and Rue have a plan to destroy the Careers' supplies.

And for the first time, I have a plan. A plan that isn't motivated by the need for flight and evasion. An offensive plan. (Collins, 2009: 207)

Besides, I'm distracted by my latest idea about the Careers and their supplies. Somehow Rue and I must find a way to destroy their food. I'm pretty sure feeding themselves will be a tremendous struggle. (Collins, 2009: 208)

The quotation above tells that the Careers are the bright tributes who are not easy to be defeated. They also never know how to be hungry because the Careers tributes have a quick strategy in the games. They first get hold all the foodstuff so that they have all the supplies needed. Katniss and Rue have an offensive plan to destroy their supplies first, then to attack them. Katniss and Rue must do a tremendous struggle to carry out their plan.

After Katniss and Peeta work together, they are eventually successful to save their life from the mutts and kill the last tribute, Cato from District 2. However, instead of being announced as the winners, the rule is revoked and only one winner is to be allowed. Katniss thinks hard to find a way so that she and Peeta can become the winners. Eventually they do dramatic love to get the sympathy from the Capitol. Their dramatic love can be seen in the following quotation:

We stand, our backs pressed together, our empty hands locked tight.

"Hold them out. I want everyone to see," he says. I spread out my fingers, and the dark berries glisten in the sun. I give Peeta's hand one last squeeze as a signal, as a good-bye, and we begin counting. ...

The frantic voice of Claudius Templesmith shouts above them. "Stop! Stop! Ladies and gentlemen, I am pleased to present the victors the Seventy-fourth Hunger Games, Katniss Everdeen and Peeta Mellark! I give you-the tributes of District twelve!'(Collins, 2009: 344-345)

The quotation above shows how Katniss and Peeta decide that they should eat poisonous nightlock berries that will kill them and leave the games with no winner. At the very moment when Katniss and Peeta are about to swalow the poisonous nightlock berries and are bidding farewell to the audiences, Claudius Templesmith shouts above them to stop their action. The Capitol's people do not want if there is no winner in the games and they see Katniss and Peeta as an act of undying love so that they are declared as the victors of the Seventy-fourth Hunger Games.

Katniss' struggle is not vain in the long run. She succeed to fulfill her family need, to protect her sister and to be a winner in the hunger games. She can receive a life of ease back home, and District 12 will be showered with prizes, largely consisting of foodstuff.

\section{Conclusion}

The above discussion leads to the conclusion of this research that the protagonist's struggles are to fulfill her family needs, to protect her sister from the hunger games and to win in the hunger games. Her protagonist's struggles are not easy and full of risks that 
endanger her own life. She must struggle to fulfill her family needs because her father died in a mine explosion which cause her mother to fall into a deep depression and be unable to think of taking care her family. She must also struggle to protect her sister because she loves her sister deeply and her sister is elected to be a tribute in the hunger games while she knows well that her sister will die if she becomes a tribute in the games. Therefore, she protects her sister life by subtituting her sister to be a tribute in the game. Besides, she must struggle to win in the hunger games because if she does not become a winner, she will die. She has no choice but to be a winner because it is a match in which the competitors must fight to the death. By winning in the Hungger Games, she not only saves her life, but also gets her family needs fulfilled since the winner of the games will be showered with prizes, particulary foodstuff.

\section{References}

Abrams, M.H. (1981). A Glossary of A Literary Term $4{ }^{\text {th }}$ Ed. New York: Holt, Rinehart and Winston.

Beckson, Karl., and Ganz, Arthur. (1990). Literary Terms: A Dictionary. Great Britain: Rupa \& Co.

Burleson, B. (1964). Human Behavior. New York: Haricot Bruce and World Inc.

Collins, C. Carter. (1978). A Student's Guide to Literature New York: Washington Square Press, Inc.

Collins, Suzanne. (2009). The Hunger Games. New York: Scholastic International Inc.

Fowler, A. Lastair. (1987). A History of Literature. London: Basil Blackwell Ltd.

Herbet, Martin. (1990). Planning a Research Project. London: Macmillan.

Hull, Jim. (2013). The True Definition of a Protagonist. http://www.narrativefirst.com/ articles/the-true-definition-of-a-protagonist. (11 December 2014).

Krishnananda, Sri Swami. (1989). The Struggle for Perfection. India: The Divine Life Society.

Koul L. (1984). Methodology of Education Research. New Delhi: Vikas Publishing House.

Maizler, Jan Stephen. (2012). Struggle and Human Growth. http://www. motivationalmagic.com (11 December 2014).

Paulo. (2011). Definition Struggle. http://www.idoceonline.com/dictionary/struggle_l. (11 December 2014).

Roehm, R. (2011). Three Types of Human Struggle. www.christianblog.com /blog/rickroehm/three-types-of-human-struggle. (11 December 2014).

Wiley, John. (2010). Webster's New World College Dictionary. Ohio: Wiley Publishing, Inc.

The Hunger Games. http://www.sparknotes.com/lit/the-hunger-games/ context.html. (11 December 2014).

Protagonist. http://literarydevices.net/protagonist. (11 December 2014). Struggle. http://www.thefreedictionary.com/struggle. (11 December 2014).

Struggle Quotes. http://thinkexist.com/quotations/struggle. (11 December 2014). 